\title{
A Case of Polymicrobial Brain Abscess Caused By a Rare Bacterium: Granulicatella elegans
}

\author{
Polimikrobiyal Etkenli Bir Beyin Apsesi Nadir Bir Bakteri Olarak: Granulicatella elegans
}

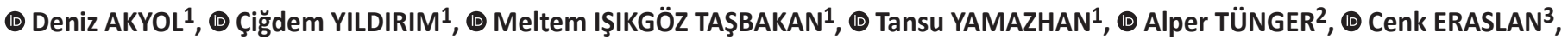 (1) Oğuz Reşat SipaHi ${ }^{1}$}

1 Ege University Faculty of Medicine, Department of Infection Diseases and Clinical Microbiology, Izmir, Turkey

2Ege University Faculty of Medicine, Department of Medical Microbiology, Izmir, Turkey

${ }^{3}$ Ege University Faculty of Medicine, Department of Radiology, Izmir, Turkey

Keywords: Beyin apsesi, Granulicatella elegans, kraniyal manyetik rezonans görüntüleme, Fusobacterium necrophorum, Peptoniphilus asaccharolyticus

Anahtar Kelimeler: Brain abscess, Granulicatella elegans, cranial magnetic resonance imaging, Fusobacterium necrophorum, Peptoniphilus asaccharolyticus

\section{Dear Editor,}

Brain abscesses are life-threatening infections that develop in the brain parenchyma and may result from contiguous spread from a local source or hematogenous spread of a systemic infection. They may be seen after trauma or intracranial surgery[1]. Streptococci are the most common cause of brain abscesses[2]. The initial findings of brain abscess are not specific. The most common symptoms are increased intracranial pressure findings such as headache, nausea and vomiting or focal neurological symptoms. Clinical presentation depends on the virulence of the microorganism. In diagnostic examinations, intracranial imaging is also important since, mostly, lumbar puncture is contraindicated in patients with brain abscess[3]. Granulicatella spp. are nutritionally variant streptococci, which were first identified as a cause of endocarditis and subsequently found to cause infections of many systems, including prosthetic joint infection and blood circulationrelated infections ${ }^{[4]}$. Meningitis and intracranial abscess due to Granulicatella elegans are very rare and frequently seen after intracranial operations ${ }^{[4]}$. There are several case reports in the literature on brain abscess due to nutritionally variant streptococci, which are cases of intracranial operations or brain abscess during immunosuppressive treatment $[5]$. Fusobacterium necrophorum is an anaerobic bacterium that may be found in the human flora. Peptoniphilus asaccharolyticus is another Grampositive anaerobic bacterium, detected among polymicrobial infections as well as in the human flora. Herein, we report a case of brain abscess, developing after tooth extraction in a 21-yearold male patient. His main complaint on admission was severe headache. He did not have any chronic disease or additional feature. Cranial magnetic resonance imaging (MRI) revealed a $3 \times 4$ $\mathrm{cm}$ sized abscess in the right temporal region. Diffusion restriction was evident inside the lesion. Abscess drainage was performed and almost $10 \mathrm{cc}$ of malodorous, yellow-green colored pus was drained. Abscess material was planted on the Columbia CNA agar with 5\% sheep blood (Biomerieux, France) and incubated for 72 hours in anaerobic conditions in a jar (Anaerob GasPak, Oxoid). Gram staining was performed from growing microorganisms on the agar. Gram-positive cocci, Gram-negative bacilli and Grampositive cocci were seen in the morphological examination. Culture of the abscess material yielded Granulicatella elegans, Fusobacterium necrophorum and Peptoniphilus asaccharolyticus. Bacteria were identified by the suggested method of matrix-

Cite this article as: Akyol D, Yıldııım Ç, Taşbakan MI, Yamazhan T, Tünger A, Eraslan C, Sipahi OR. A Case of Polymicrobial Brain Abscess Caused By a Rare Bacterium: Granulicatella elegans. Mediterr J Infect Microb Antimicrob. 2018;7:3. 
assisted laser desorption/ionization analysis-time of flight with VITEK $^{\circledR}$ MS (France) system[6]. Antibacterial susceptibility data for these bacteria could not be obtained because antimicrobial susceptibility testing of anaerobic bacteria was not being performed in the microbiology laboratory at our hospital. Mycological, mycobacterial cultures and parasitological examination did not yield any pathogen. Pathological examination was compatible with brain abscess. Other infectious foci for abscess etiology were investigated by chest X-ray, abdominal ultrasonography and echocardiography. However, no further focus was identified. Laboratory examination was as follows; blood leukocyte: $11.84 \times 10^{3}$ /mL (68\% neutrophil), C-reactive protein: $17.93 \mathrm{~g} / \mathrm{dL}$ (N: 0-0.5 g/ $\mathrm{dL}$ ), erythrocyte sedimentation rate: $38 \mathrm{~mm} / \mathrm{h}$, and liver and kidney function tests were normal. Empirical antibiotherapy was started with ceftriaxone and metronidazole and ceftriaxone was switched to penicillin with identification of the etiologic agents. However, after penicillin administration, the patient developed an allergic reaction in the form of erythema and itchy rashes on the whole body, thus, penicillin was switched to linezolid. Antibiotherapy was given for six weeks intravenously. Repeat cranial MRI performed after six weeks of intravenous treatment revealed a significant decrease in the abscess size $(1.2 \times 1 \mathrm{~cm})$. He was discharged with oral phenoxymethyl penicillin. Clinical, laboratory and radiological improvement were achieved after a total of 10 weeks of antibiotic treatment. There was no relapse after three months of follow-up.

Brain abscess is an infectious disease requiring a multidisciplinary approach. It may cause severe mortality and morbidity. The incidence of brain abscess has been reported to range between 0.3 and 1.3/100.000[7]. The most frequent complaint is headache. Since lumbar puncture is considered to be contraindicated[1], cranial imaging is the most valuable method for diagnosis and follow-up. Radiological imaging is also a guide in determining the duration of treatment. Empirical therapy includes broad-spectrum antibiotics with an anaerobic activity and high blood-brain barrier penetration. Etiology-oriented therapy is important in the proper management. After the etiologic agents were identified in our case, ceftriaxone was switched to penicillin considering the studies in the literature [8,9]. Linezolid which is an alternative treatment option for central nervous system infections was preferred after an allergic reaction with penicillin developed[1]. Due to possible side effects of vancomycin, linezolid was preferred. However, contrary to our case, it is not always possible to perform drainage especially in locations where drainage is not conceivable. In the presented case, the diagnosis was confirmed microbiologically, radiologically and pathologically. Sampling is important in making treatment decision as performed in our case. Long-term antibiotic treatment after surgical drainage was successful without mortality or morbidity.

This case was presented to draw attention to microbiologic sampling which confers directed therapy and delineates the rarely encountered etiologic agents such as Granulicatella spp. as well. To our knowledge this is the first case of brain abscess caused by Granulicatella elegans after tooth extraction.

\section{Acknowledgements}

Authors thank the European Study Group for Infections of the Brain (ESGIB) for interpretation of the manuscript.

\section{Ethics}

Informed Consent: The consent form is not needed for this submission.

Peer-review: Externally peer-reviewed.

\section{Authorship Contributions}

Microbiological and Radiological Assessment: A.T., C.E., Concept: Design: M.I.T., T.Y., Data Collection or Processing: Analysis or Interpretation: M.I.T., T.Y., O.R.S., Literature Search: D.A., C..Y., Writing: D.A., Ç.Y., O.R.S.

Conflict of Interest: No conflict of interest was declared by the authors.

Financial Disclosure: The authors declared that this study received no financial support.

\section{References}

1. Van de Beek D, Cabellos C, Dzupova O, Esposito S, Klein M, Kloek AT, Leib SL, Mourvillier B, Ostergaard C, Pagliano P, Pfister HW, Read RC, Sipahi OR, Brouwer MC; ESCMID Study Group for Infections of the Brain (ESGIB). ESCMID guideline: diagnosis and treatment of acute bacterial meningitis. Clin Microbiol Infect. 2016;22(Suppl 3):37-62.

2. Helweg-Larsen J, Astradsson A, Richhall H, Erdal J, Laursen A, Brennum J. Pyogenic Brain Abscess, A 15 year Survey. BMC Infectious Diseases. 2012;12:332.

3. Alvis Miranda $\mathrm{H}$, Castellar-Leones SM, Elzain MA, Moscote-Salazar LR. Brain Abscess: Current Management. J Neurosci Rural Pract. 2013;4(Suppl 1):6781.

4. Shivappa SG, Kulkarni M, Manjula SR, Oral B. Granulicatella elegans Bacteremia \&t Meningitis in a Child without Neurosurgical Interventions. Journal of Dental and Medical Sciences. 2014;13:1-4.

5. Zenone T, Durand DV. Brain abscesses caused by Abiotrophia defectiva: complication of immunosuppressive therapy in a patient with connectivetissue disease. Scand J Infect Dis. 2004;36:497-9.

6. Procop GW, Church DL, Hall GS, Janda WM, Koneman EW. The Anaerobic Bacteria. Koneman's Color Atlas and Textbook of Diagnostic Microbiology, 7th ed. Philadelphia: Wolters Kluwer; 2017:983-1073.

7. Klein M, Pfister HW, Tunkel AR. Brain abscess. In: Scheld WM, Whitley RJ, Marra CM, editors. Infections of the Central Nervous System. 4th ed. Philadelphia: Lippincott Williams \& Wilkins. 2014;p.550.

8. Alberti MO, Hindler JA, Humphries RM. Antimicrobial Susceptibilities of Abiotrophia defectiva, Granulicatella adiacens, and Granulicatella elegans. Antimicrob Agents Chemother. 2016;60:1411-20.

9. Prasidthrathsint K, Fisher MA. Antimicrobial Susceptibility Patterns among a Large, Nationwide Cohort of Abiotrophia and Granulicatella Clinical Isolates. J Clin Microbiol. 2017;55:1025-31. 